\title{
ANALISIS KEMAMPUAN SISWA DALAM MENYELESAIKAN SOAL CERITA MATEMATIKA DI SMP KARTIKA VIII-1 JAKARTA
}

\author{
Yosua $^{1}$, Indra Martha Rusmana ${ }^{2}$ \\ ${ }^{1,2)}$ Program Studi Pendidikan Matematika, FMIPA, Universitas Indraprasta PGRI Jakarta \\ yosuamanurung88@gmail.com ${ }^{1}$, indramartharusmana@ymail.com ${ }^{2}$
}

\begin{abstract}
This study aims to determine the ability of students in solving math story problems at SMP Kartika VIII-1. Another objective is to analyze the students' ability to solve math story problems at SMP Kartika VIII-1. The method used to analyze the ability is a qualitative method by collecting data through a story question test to describe the student's ability to solve story questions. The ability to understand story problems with a very high category, the ability to plan strategy solving strategies for story problems with a sufficient category, the ability to implement a strategy for solving story problems with a high category, and the ability to prove the truth of the results with a low category. Keywords: Student Abilities, math story problems.
\end{abstract}

\begin{abstract}
Abstrak
Penelitian ini bertujuan untuk mengetahui kemampuan siswa dalam menyelesaikan soal cerita matematika di SMP Kartika VIII-1. Tujuan yang lain adalah untuk menganalisis kemampuan siswa dalam menyelesaikan soal cerita matematika di SMP Kartika VIII-1. Metode yang digunakan untuk menganalisis kemampuan adalah metode kualitatif dengan cara pengumpulan data melalui tes soal cerita untuk menggambarkan kemampuan siswa dalam menyelesaikan soal cerita. Kemampuan memahami soal cerita dengan kategori sangat tinggi, kemampuan merencanakan strategi penyelesaian soal cerita dengan kategori cukup, kemampuan melaksanakan strategi penyelesaian soal cerita dengan kategori tinggi, dan kemampuan membuktikan kebenaran hasil dengan kategori kurang.
\end{abstract}


Jurnal Lebesgue : Jurnal Ilmiah Pendidikan Matematika, Matematika dan Statistika

Yosua, Indra Martha Rusmana

Volume 2, No. 3, Desember 2021 hal.225-233

DOI Artikel : 10.46306/lb.v2i3.36

\section{PENDAHULUAN}

Pendidikan pada dasarnya adalah suatu proses untuk membantu manusia mengembangkan dirinya sehingga mampu menghadapi segala bentuk perubahan dan permasalahan dengan sikap terbuka serta pendekatan kreatif tanpa kehilangan jati dirinya. Hal ini ditegaskan dalam Undang-undang No. 2 tahun 1989 (Usman, 2002) bahwa pendidikan berfungsi untuk mengembangkan kemampuan serta meningkatkan mutu kehidupan dan martabat manusia Indonesia dalam upaya mewujudkan tujuan nasional.

Sebagaimana menurut pendapat Davies (Mardianto, 2012: 54), pendidikan intinya adalah pembelajaran. Pembelajaran adalah proses interaksi peserta didik dengan pendidik dan sumber belajar pada suatu lingkungan belajar. Oleh karena itu, pendidik harus dapat melakukan interaksi sebaik-baiknya dengan peserta didik dalam kegiatan pembelajaran agar materi yang disampaikan oleh pendidik dapat dipahami dan dimengerti oleh peserta didik, bahkan dapat menarik partisipasi siswa, sehingga pendidik tersebut dapat dikatakan berhasil dalam melaksanakan pembelajaran.

Kegiatan pembelajaran yang dibangun oleh guru dan siswa adalah kegiatan yang apabila segala sesuatu yang dilakukan guru dan siswa hendaknya diarahkan untuk mencapai tujuan yang telah ditentukan. Dengan demikian setting pembelajaran tujuannya merupakan pengikat segala aktivitas guru dan siswa. Oleh sebab itu, merumuskan tujuan pembelajaran merupakan langkah utama yang harus dilakukan dalam merancang sebuah program pembelajaran. Sehingga kegiatan pembelajaran dapat terlaksana dengan baik terutama dalam pembelajaran matematika.

Pembelajaran matematika merupakan suatu proses belajar mengajar yang mengandung dua jenis kegiatan yang tidak terpisahkan. Kegiatan tersebut adalah belajar mengajar. Pembelajaran matematika adalah suatu proses belajar mengajar yang dibangun oleh guru untuk mengembangkan kreativitas berpikir siswa yang dapat meningkatkan kemampuan berpikir siswa, serta dapat meningkatkan kemampuan mengkontruksi pengetahuan baru sebagai upaya penguasa yang baik terhadap matematika.

Matematika merupakan salah satu ilmu dasar yang sangat menentukan penguasaan teknologi yang dimiliki oleh suatu bangsa. Hal ini seperti yang dikemukakan oleh Fathani (2016) kemampuan matematis juga meliputi kemampuan bernalar yang logis dan kritis dalam pemecahan masalah. Pemecahan masalah ini tidak semata-mata masalah yang berupa soal rutin akan tetapi lebih kepada permasalahan yang dihadapi sehari-hari. Matematika merupakan salah satu ilmu dasar yang mempunyai peranan penting baik dalam kehidupan sehari-hari maupun 
Jurnal Lebesgue : Jurnal Ilmiah Pendidikan Matematika, Matematika dan Statistika

Yosua, Indra Martha Rusmana

Volume 2, No. 3, Desember 2021 hal.225-233

DOI Artikel : 10.46306/lb.v2i3.36

dalam pengembangan ilmu dan teknologi. Ilmu pengetahuan dan teknologi dapat dibina dalam kerangka-kerangka landasan mata pelajaran matematika, sehingga penguasaan pelajaran matematika berperan penting pada kemajuan teknologi. Matematika dibutuhkan untuk memecahkan masalah dalam berbagai kehidupan manusia. Dalam perkembangan pembelajaran matematika, muncul pendekatan kontekstual yang mengaitkan antara materi matematika yang diajarkan di sekolah dengan kehidupan sehari-hari siswa. Siswa secara aktif membangun, melengkapi dan memahami konsep-konsep matematika secara benar. Materi pembelajaran dikembangkan dari situasi nyata dan yang telah didengar, dilihat, atau dialami sendiri oleh siswa. Oleh karena itu, dalam memberikan pengalaman belajar kepada siswa diawali dengan sesuatu yang nyata bagi mereka. Pemberian soal cerita matematika pada siswa diharapkan memenuhi tujuan pembelajaran kontekstual yaitu siswa dapat merasakan adanya keterkaitan antara materi matematika yang didapatkan di sekolah dengan kehidupan nyata.

Spencer and Spencer mendefinisikan kemampuan sebagai karakteristik yang menonjol dari seorang individu yang berhubungan dengan kinerja efektif dan atau superior dalam suatu pekerjaan atau situasi (Uno, 2006: 129). Dengan demikian, kemampuan siswa dalam menyelesaikan soal matematika dalam bentuk cerita meliputi beberapa langkah penyelesaian yaitu kemampuan memahami soal, membuat model matematika, dan perhitungan. Jika salah satu langkah penyelesaian terdapat kesalahan, maka akan menyebabkan kesalahan pada langkah selanjutnya dan mengakibatkan rendahnya hasil yang diperoleh siswa dalam menyelesaikan soal matematika dalam bentuk cerita.

Soal cerita matematika adalah soal yang di dalamnya merupakan soal matematika tetapi disajikan dalam bentuk soal cerita yang menggambarkan permasalahan sehari-hari yang dalam penyelesaiannya diperlukan daya nalar tinggi untuk dapat mengartikan soal tersebut ke dalam bahasa matematika. Dalam menyelesaikan soal cerita matematika, ada beberapa langkah yang harus diperhatikan, yaitu pemahaman fakta yang meliputi menentukan yang diketahui dan yang ditanyakan, pembuatan model, penyelesaian model matematika, serta meyimpulkan jawaban soal cerita matematika. Ashlock (2003:80) yang menyatakan bahwa soal cerita merupakan soal yang dapat disajikan dalam bentuk lisan maupun tulisan yang mengilustrasikan kegiatan dalam kehidupan sehari-hari. Soal cerita yang diajarkan diambil dari hal-hal yang terjadi dalam kehidupan sekitar juga dari pengalaman siswa. Demikian pula soal cerita hendaknya meliputi aplikasi secara praktis situasi sosial ataupun beberapa lapangan studi yang mungkin.

Namun pada kenyataannya, matematika menjadi salah satu pelajaran yang tidak diminati dan dianggap sulit oleh siswa di setiap jenjang pendidikan. Salah satunya yaitu dalam 
menyelesaikan soal matematika bentuk cerita. Soal cerita disajikan dalam bentuk cerita dan masalah yang diungkapkan merupakan masalah kehidupan sehari-hari. Kebanyakan siswa merasa kesulitan dalam memahami maksud dari soal yang diberikan, apa yang ditanyakan dalam soal tersebut, dan masih banyak pula terdapat kesalahan dalam perhitungan. Hal itu dikarenakan dalam menyelesaikan soal matematika dalam bentuk cerita diperlukan langkahlangkah pemahaman dan daya nalar yang tinggi. Masih banyak siswa yang kurang memahami bagaimana menerjemahkan kalimat sehari-hari soal ke dalam kalimat matematika atau model matematika. Tujuan dari penelitian ini adalah untuk menganalisis kemampuan siswa dalam menyelesaikan soal cerita matematika di SMP Kartika VIII-1 Jakarta.

\section{METODE PENELITIAN}

Jenis penelitian yang digunakan dalam penelitian ini adalah deskriptif kualitatif. Penelitian deskriptif adalah penelitian yang digunakan untuk menggambarkan (to describe), menjelaskan dan menjawab persoalan-persoalan tentang fenomena dan peristiwa yang terjadi saat ini, baik tentang fenomena sebagaimana adanya maupun analisis hubungan antara berbagai variabel dalam suatu fenomena (Arifin, 2011: 41). Penelitian kualitatif adalah penelitian yang bermaksud untuk memahami fenomena tentang apa yang dialami oleh subjek penelitian misalnya perilaku, persepsi, motivasi, tindakan, dll (Moleong, 2007:6). Metode pengumpulan data yang digunakan dalam penelitian ini adalah berupa tes tertulis, wawancara, dan dokumentasi.

Instrumen dalam penelitian ini yaitu tes tertulis, wawancara, dan dokumentasi. Tes yang digunakan dalam penelitian ini adalah tes bentuk uraian yang digunakan untuk mengumpulkan data kemampuan siswa, wawancara untuk mengumpulkan data faktor-faktor penyebab kesalahan siswa dalam menyelesaikan soal, dan Dokumentasi diperlukan untuk menambah informasi subjek penelitian.

\section{HASIL DAN PEMBAHASAN}

Untuk menentukan kategori kemampuan siswa kelas IX-B dalam memahami masalah soal cerita, maka digunakan interval sebagai berikut: 
Jurnal Lebesgue : Jurnal Ilmiah Pendidikan Matematika, Matematika dan Statistika

Yosua, Indra Martha Rusmana

Volume 2, No. 3, Desember 2021 hal.225-233

DOI Artikel : 10.46306/lb.v2i3.36

Tabel 1. Pengkategorian Kemampuan Siswa

\begin{tabular}{cl}
\hline $\begin{array}{c}\text { Interval } \\
\text { (Jumlah Jawaban Benar) }\end{array}$ & \multicolumn{1}{c}{ Kategori } \\
\hline $145-180$ & Sangat Tinggi \\
\hline $109-144$ & Tinggi \\
\hline $73-108$ & Cukup \\
\hline $37-72$ & Kurang \\
\hline $1-36$ & Sangat Kurang \\
\hline
\end{tabular}

\section{Kemampuan Siswa Memahami Masalah Soal Cerita}

Setelah dilakukan tes tertulis sebanyak 6 soal yang setiap soalnya terdiri dari 4 butir pertanyaan pada hari Selasa tanggal 28 Juli 2020 yang diujikan kepada 30 siswa, diperoleh data dari hasil kerja siswa pada tes tertulis adalah terdapat 16 siswa yang dapat menuliskan apa yang diketahui dan apa yang ditanya dari soal cerita sebanyak 6 soal, 4 siswa yang dapat menuliskan apa yang diketahui dan apa yang ditanya dari soal cerita sebanyak 5 soal, 5 siswa yang dapat menuliskan apa yang diketahui dan apa yang ditanya dari soal cerita sebanyak 4 soal, 2 siswa yang dapat menuliskan apa yang diketahui dan apa yang ditanya dari soal cerita sebanyak 3 soal, dan 3 siswa yang dapat menuliskan apa yang diketahui dan apa yang ditanya dari soal cerita sebanyak 2 soal.

Berdasarkan kategori pada tabel 1, dianalisa bahwa kemampuan siswa kelas IX-B memahami masalah soal cerita kategori sangat tinggi. Hal ini ditunjukkan terdapat 148 dari jumlah jawaban yang benar.

\section{Kemampuan Siswa Merencanakan Strategi Penyelesaian Soal Cerita}

Setelah dilakukan tes tertulis sebanyak 6 soal yang setiap soalnya terdiri dari 4 butir pertanyaan pada hari Selasa tanggal 28 Juli 2020 yang diujikan kepada 30 siswa, diperoleh data dari hasil kerja siswa pada tes tertulis adalah terdapat 5 siswa yang dapat menyusun model matematika dari soal cerita sebanyak 6 soal, 5 siswa yang dapat menyusun model matematika dari soal cerita sebanyak 5 soal, 7 siswa yang dapat menyusun model matematika dari soal cerita sebanyak 4 soal, 4 siswa yang dapat menyusun model matematika dari soal cerita sebanyak 3 soal, 5 siswa yang dapat menyusun model matematika dari soal cerita sebanyak 2 soal, dan 2 siswa dapat menyusun model matematika dari soal cerita sebanyak 1 soal.

Berdasarkan kategori pada tabel 1, Kemampuan siswa kelas IX-B merencanakan strategi penyelesaian soal cerita kategori cukup. Hal ini ditunjukkan terdapat 107 jumlah jawaban yang benar.

\section{Kemampuan Siswa Melaksanakan Strategi Penyelesaian Soal Cerita}

Setelah dilakukan tes tertulis sebanyak 6 soal yang setiap soalnya terdiri dari 4 butir 
Jurnal Lebesgue : Jurnal Ilmiah Pendidikan Matematika, Matematika dan Statistika

Yosua, Indra Martha Rusmana

Volume 2, No. 3, Desember 2021 hal.225-233

DOI Artikel : 10.46306/lb.v2i3.36

pertanyaan pada hari Selasa tanggal 28 Juli 2020 yang diujikan kepada 30 siswa, diperoleh data dari hasil kerja siswa pada tes tertulis adalah terdapat 11 siswa yang dapat menyelesaikan model matematika dari soal cerita sebanyak 6 soal, 4 siswa yang dapat menyelesaikan model matematika dari soal cerita sebanyak 5 soal, 10 siswa yang dapat menyelesaikan model matematika dari soal cerita sebanyak 4 soal, 2 siswa yang dapat menyelesaikan model matematika dari soal cerita sebanyak 3 soal, 2 siswa dapat menyelesaikan model matematika dari soal cerita sebanyak 2 soal, dan seorang siswa dapat menyelesaikan model matematika dari soal cerita sebanyak 1 soal.

Berdasarkan kategori pada tabel 1, Kemampuan siswa kelas IX-B melaksanakan strategi penyelesaian soal cerita kategori tinggi. Hal ini ditunjukkan terdapat 137 jumlah jawaban yang benar.

\section{Kemampuan Siswa Membuktikan Kebenaran Jawaban dan Menginterprestasikannya dalam Penyelesaian Soal Cerita}

Setelah dilakukan tes tertulis sebanyak 6 soal yang setiap soalnya terdiri dari 4 butir pertanyaan pada hari Selasa tanggal 28 Juli 2020 yang diujikan kepada 30 siswa, diperoleh data dari hasil kerja siswa pada tes tertulis adalah terdapat 2 siswa yang dapat membuktikan kebenaran jawaban dan menginterpretasikannya dalam penyelesaian soal cerita sebanyak 6 soal, 2 siswa yang dapat membuktikan kebenaran jawaban dan menginterpretasikannya dalam penyelesaian soal cerita sebanyak 5 soal, 3 siswa yang dapat membuktikan kebenaran jawaban dan menginterpretasikannya dalam penyelesaian soal cerita sebanyak 4 soal, 2 siswa yang dapat membuktikan kebenaran jawaban dan menginterpretasikannya dalam penyelesaian soal cerita sebanyak 3 soal, 11 siswa yang dapat membuktikan kebenaran jawaban dan menginterpretasikannya dalam penyelesaian soal cerita sebanyak 2 soal dan 8 siswa dapat membuktikan kebenaran jawaban dan menginterpretasikannya dalam penyelesaian soal cerita sebanyak 1 soal.

Berdasarkan kategori pada tabel 1, Kemampuan siswa kelas IX-B membuktikan kebenaran jawaban dan mengintrprestasikannya dalam penyelesaian soal cerita kategori kurang. Hal ini ditunjukkan terdapat 70 jumlah jawaban yang benar.

Berikut pembahasan mengenai kesulitan dan faktor penyebab siswa mengalami kesulitan dalam menyelesaikan soal matematika bentuk cerita khususnya materi SPLDV :

a. Siswa S23 (Kategori kemampuan tinggi) 

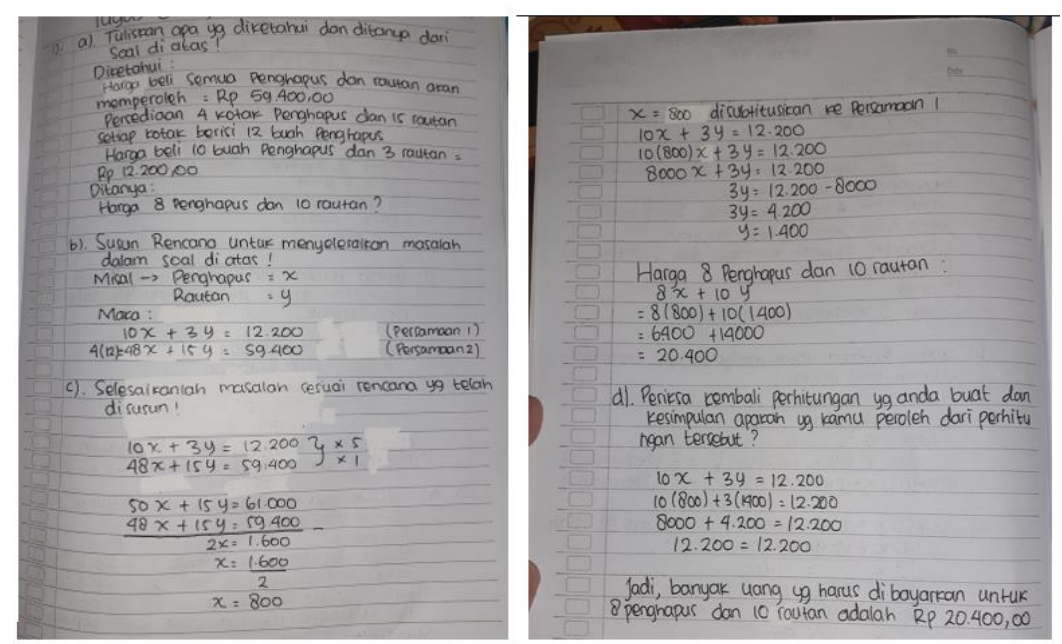

Berdasarkan jawaban siswa di atas, siswa mampu memahami masalah soal cerita, merencanakan strategi penyelesaian soal cerita, melaksanakan strategi penyelesaian soal cerita, membuktikan kebenaran jawaban dan menginterpretasikannya. Disimpulkan bahwa siswa S23 tidak mengalami kesulitan. Dari hasil wawancara dengan siswa S23 diketahui bahwa kemampuan siswa S23 dalam menyelesaikan soal cerita karena siswa memahami konsep SPLDV, sering latihan di rumah dan membahas soal di bimbingan belajar.

b. Siswa S18 (Kategori kemampuan sedang)

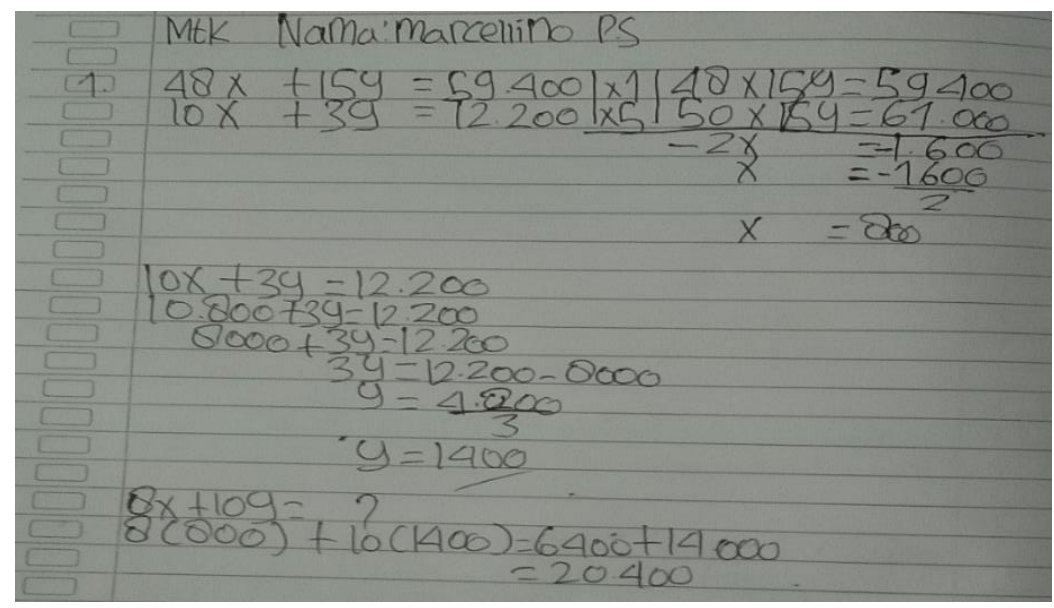

Berdasarkan jawaban siswa di atas, siswa kurang mampu memahami masalah soal cerita dan merencanakan strategi penyelesaian soal cerita tetapi mampu dalam menyelesaikan model matematika dari soal cerita dan tidak terdapat pembuktikan kebenaran jawaban dan interpretasinya. Disimpulkan bahwa siswa S18 kesulitan pada tahap pelaksanaan strategi penyelesaian soal cerita dan pembuktian kebenaran jawaban dan mnginterpretasikannya. Dari hasil wawancara dengan siswa S18 diketahui bahwa kesulitan siswa S18 dalam menyelesaikan soal cerita karena siswa ingin menyelesaikan soal dengan cepat, tidak terbiasa membuktikan kebenaran jawaban dan menginterpretasikannya, kurangnya latihan di rumah dan kurangnya 
pada saat melakukan perhitungan.

c. Siswa S11 (Kategori kemampuan rendah)

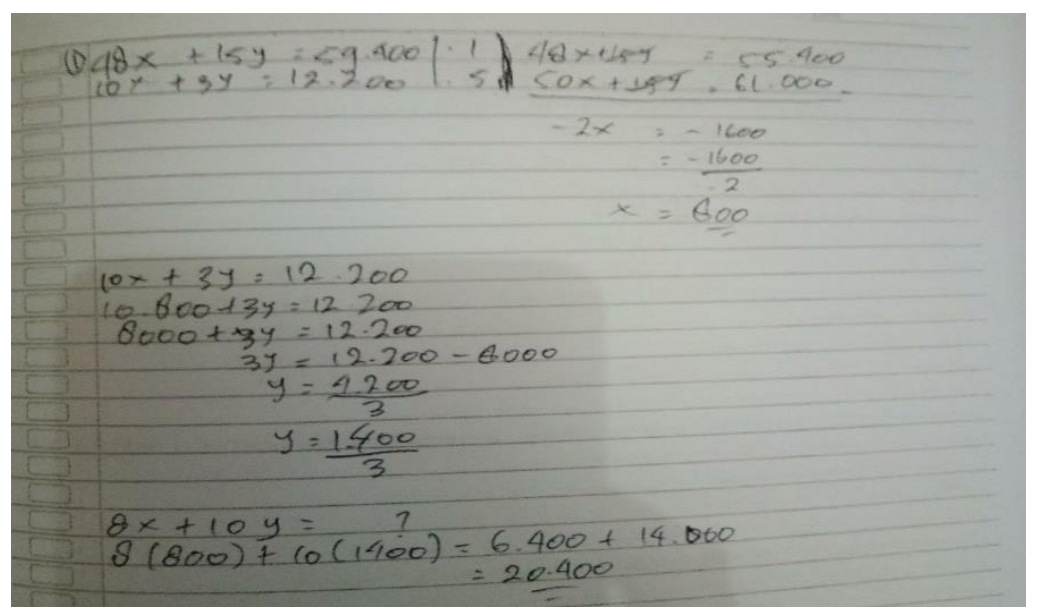

Berdasarkan jawaban siswa di atas, siswa mampu memahami masalah soal cerita dan merencanakan strategi penyelesaian soal cerita tetapi mengalami kesalahan dalam menyelesaikan model matematika dari soal cerita, tidak terdapat pembuktikan kebenaran jawaban dan tidak terdapat kesimpulan, siswa menjawab hanya sebatas sampai himpunan penyelesaian. Disimpulkan bahwa siswa S11 kesulitan pada tahap pelaksanaan strategi penyelesaian soal cerita dan pembuktian kebenaran jawaban dan menginterpretasikannya. Dari hasil wawancara dengan siswa S11 diketahui bahwa kesulitan siswa S11 dalam menyelesaikan soal cerita karena siswa tidak terbiasa membuktikan kebenaran jawaban, kurang teliti dalam hal perhitungan sehingga berdampak pada penarikan kesimpulan, tidak sering latihan di rumah.

\section{KESIMPULAN}

Berdasarkan hasil penelitian dan pembahasan, maka dapat diperoleh beberapa kesimpulan sebagai berikut:

1. Kemampuan siswa kelas IX-B SMP Kartika VIII-1 dalam menyelesaikan soal cerita matematika materi SPLDV, yaitu:

a) Kemampuan siswa memahami masalah soal cerita pada materi SPLDV kategori sangat tinggi. Hal ini ditunjukkan dari kalkulasi butir pertanyaan dengan jumlah seluruh siswa yaitu sejumlah 180 butir pertanyaan terdapat 148 butir pertanyaan dijawab benar yaitu dengan menuliskan apa yang diketahui dan ditanya.

b) Kemampuan siswa merencanakan strategi penyelesaian soal cerita pada materi SPLDV kategori cukup. Hal ini ditunjukkan dari kalkulasi butir pertanyaan dengan 
jumlah seluruh siswa yaitu sejumlah 180 butir pertanyaan terdapat 107 butir pertanyaan dijawab benar yaitu dengan menyusun model matematika.

c) Kemampuan siswa melaksanakan strategi penyelesaian soal cerita pada materi SPLDV kategori tinggi. Hal ini ditunjukkan dari kalkulasi butir pertanyaan dengan jumlah seluruh siswa yaitu sejumlah 180 butir pertanyaan terdapat 137 butir pertanyaan dijawab benar yaitu dengan menyelesaikan model matematika.

d) Kemampuan siswa membuktikan kebenaran hasil dan menginterpretasikaannya dalam penyelesaian soal cerita pada materi SPLDV kategori kurang. Hal ini ditunjukkan dari kalkulasi butir pertanyaan dengan jumlah seluruh siswa yaitu sejumlah 180 butir pertanyaan terdapat 70 butir pertanyaan dijawab benar yaitu dengan membuktikan kebenaran jawaban dan menginterpretasikannya dalam penyelesaian soal cerita.

2. Kesulitan yang dialami siswa yaitu pada tahap merencanakan strategi penyelesaian soal cerita yaitu dalam menerjemahkan soal ke dalam model matematika, pada tahap membuktikan kebenaran hasil dan menuliskan kesimpulan.

3. Faktor- faktor penyebab kesulitan siswa dalam menyelesaikan soal cerita SPLDV antara lain adalah karena faktor internal dan eksternal. Faktor internal yaitu, minat, keadaan fisik yang tidak mendukung seperti: lelah dan mengantuk, keadaan psikis yang tidak mendukung seperti: malas, jenuh, dan tertekan/terbebani. Faktor eksternalnya yaitu dukungan dan pengawasan orang tua serta pergaruh dari teman.

\section{DAFTAR PUSTAKA}

Arifin, Z. (2011). Penelitian Pendidikan. Bandung: PT Remaja Rosdakarya.

Ashlock. (2003). Guiding Each Child's Learning of Mathematics. Colombus: Bell Company.

Fathani, A.H. (2016). Pengembangan Literasi Matematika Sekolah dalam Perspektif Multiple Intelligences, Jurnal EduSains 4(2), 136-150.

Mardianto. (2012). Landasan untuk Pengembangan Strategi Pembelajaran. Cet. II (Medan: Perdana Publishing, 2012).

Moleong, L. J. (2007). Metode Penelitian Kualitatif. Bandung: Remaja Rosdakarya

Mubarok, A., \& Dewi, E. Y. (2021). ANALISIS KESALAHAN PESERTA DIDIK SMP DALAM MENYELESAIKAN SOAL KEMAMPUAN BERPIKIR KRITIS BERDASARKAN NEWMAN. Jurnal Lebesgue: Jurnal Ilmiah Pendidikan Matematika, Matematika dan Statistika, 2(1), 121-135.

Petronela, S., \& Pranyata, Y. I. P. (2020). ANALISIS KESALAHAN SISWA PASIF DALAM MENYELESAIKAN SOAL MATEMATIKA BERBENTUK CERITA. Jurnal Lebesgue: Jurnal Ilmiah Pendidikan Matematika, Matematika dan Statistika, 1(3), 172-181.

Undang-undang Republik Indonesia Nomor 2 tentang Sistem Pendidikan Nasional. 1990. Jakarta: PT. Armas Duta Jaya

Uno, H.B. (2006). Orientasi Baru dalam Psikologi Pembelajaran. Jakarta: Bumi Aksara. Usman, Uzer.(2002). Menjadi Guru Profesional. Bandung: PT. Remaja Rosdakarya. 